\title{
DIADEMMA: A tool to promote peer-mentoring in Colombian higher education
}

\author{
Ana María Vargas Betancur, Diego Ernesto Leal Fonseca, Leydy Johana García Pineda \\ Center for Excellence in Learning (EXA), EAFIT University, Colombia.
}

\begin{abstract}
Mentoring programs in higher education have gained importance in recent years for their contribution to the development of professional and personal skills, as well as improving student retention and completion. Considering this, the program Generation E, -created by the Colombian Ministry of Education to provide socioeconomic support to underprivileged youth for their access to higher education-, started to include mentoring strategies in 2019 as a key element to foster completion. In 2020, a development model was designed to assess the situation of these programs in higher education institutions across the country. This article describes an analytic tool-called DIADEMMA (Diagnosis of Mentoring Moments Development) - which articulates five development moments with six factors key to any mentoring program, drawing on a structure proposed by an existing model for the assessment of higher education programs for student retention in Colombia. The first implementation of DIADEMMA allowed to identify the status of peermentoring initiatives in an initial group of institutions, providing input to define actions to support their consolidation, considering the nature and possibilities of each one of them.
\end{abstract}

Keywords: Mentoring; higher education; development Model; DIADEMMA. 


\section{Introduction}

Student attrition in Latin America is a worrying phenomenon for international, regional and local governments and agencies. The Observatory of Higher Education of Medellin, Colombia-ODES- (2017), reports that Latin America attrition rates range from $40 \%$ to $75 \%$, while the Colombian Association of Universities -ASCUN-, cited in Suárez-Castrillón et al (2020), notes that $45 \%$ of young people who start post-secondary studies in Colombia don't finish them.

In 2018, the Colombian government, by means of the Ministry of Education (MoE), launched the Generation E Program, with the aim of promoting access to higher education as well as completion by youth in condition of economic vulnerability. By the end of 2020, there were 113 Higher Education Institutions (HEI) participating in the program (out of a total of 300 registered HEI), benefiting around 160,000 students. Generation $E$ contributes with: a grant that covers tuition and partial support; the development of welfare strategies; and the generation of networks that connect students with local entrepreneurship ecosystems. However, previous experiencies with similar programs suggested that providing support for student integration to higher education is as important as supporting access (AndradeFernandez et al, 2017; Alvarez-Rivadulla, 2019; Diaz-Velasquez, 2019). Thus, in 2019 the MoE convened EAFIT University and the Cooperative University of Colombia to collaborate in the design of a Mentoring Program which was first deployed in the second half of 2020.

Given that student retention ${ }^{1}$ represents a shared concern between MoE and HEI, in recent years several alternatives have been explored to seek the development of the personal and academic skills needed for students to succeed, such as peer support (which in many cases involves peer learning). This strategy is characterized by the participation of students of advanced semesters in activities or programs where they support their peers outside the classroom, either for their integration into higher education, support in understanding curriculum subjects, or adaptation to city life -in the cases where they arrive from other regions or countries. Broadly, peer support involves an interaction between peers that encourages the exchange of knowledge or experiences. In Colombian HEI there is a high heterogeneity in the objectives, scopes and characteristics of these type of strategies, which is reflected in the great diversity of denominations found in the sector -tutoring, monitoring, mentoring, among others-. It should be noted that, for the specific case of mentoring

\footnotetext{
${ }^{1}$ Recently, the word retention has started to be replaced in local discourse by the word permanence (Spanish permanencia, meaning to stay, to remain), as a way to put emphasis in the outcome expected from the student (to remain in the education system), instead of the action carried on by the HEI. However, retention will be used in this text, given its pervasive use in English-based higher education.
} 
initiatives, not all of those called this way correspond to what is described in the literature, while others fulfill their characteristics even if they are called otherwise.

Considering this situation, the first step for the implementation of the Generation $E$ Mentoring Program was an assessment of the type of strategies developed by HEI, their degree of development and the feasibility of articulating the proposed Mentoring Program to existing initiatives.

\section{A development model for mentoring programs in higher education}

A maturity model shows how an initiative evolves, "allowing to identify on which step it is, so it can make the required improvements to advance to the next step" (De Freitas, 2018, p. 7); according to this author it is not that common to find such models in higher education institutions. Maturity models indicate the levels of qualitative developments, the parameters that describe them and the conditions for advancement or maturation from an initial condition to a condition reached (p. 11). Maturity models can be built according to the needs and objectives of each organization, and, thanks to them, it is possible to have a benchmark reference to identify at what stage a process, program or strategy is located, and what actions are needed to foster its development.

In this sense, the formulation of a development model for mentoring programs became the initial step to identify the status of such initiatives in Colombian HEI, using as reference the literature review on the definition of mentoring, its history, contexts, types, modes of delivery and, in particular, its role in Ibero-American higher education. The work of Casado-Muñoz, Lezcano-Barbero and Colomer-Felui (2015) in their article "Ten key steps to developing a programme of university mentoring for newly enrolled students" was especially relevant, describing both structural components related to the institutional commitment to the program -such as availability of resources, assessment \& evaluation- and substantial elements related to its nature -such as assessment of needs, recruitment and training of mentors. Additional recommendations about the creation of successful mentoring programs in other areas (Chronus, 2017; National Mentoring Partnership, 2019; Mentors4U, 2021) were included in the literature review.

In the design of the national-level Generation E Mentoring Program, seven elements for action were defined to be addressed in iterative stages, according to the conditions of each HEI:

- Attracting, focused on the processes of stakeholder communication and recruitment of mentors and mentees.

- Knowing, aimed to identify the entry conditions and the needs for guidance and learning of the different actors of the process. 
- Connecting, dedicated to pairing mentors and mentees according to criteria defined in the characterization, in order to foster the creation of connections between them.

- Guidance, focused on the development or mentoring skills in mentors as well as skills for life and career plan in mentees.

- Evaluating, which includes the processes of monitoring, assessment and evaluation of the actions, outcomes, results and impact of the program, according to its theory of change.

- Articulating, which refers to the coordination between MoE and HEI on the subject of mentoring, to give consistency to the program and weave networks that promote the sustainability of the strategy.

- Technological platform, which supports the structural dimension -data management systems, information and analytics- as well as the substantial dimension of the program - training, guidance and interaction of the participants.

On the other hand, the development model identifies a set of key factors for a formal mentoring program at the HEI level, which can be articulated with the elements for action mentioned above:

- Positioning, which refers to the articulation of mentoring programs with existing programs, processes and policies of well-being or student retention.

- Monitoring, related to the identification of results and impact of the program, as input to its continuous improvement.

- Management, referring to the involvement of mentors and mentees in the program in order to achieve its objectives.

- Training, which includes the activities established for the onboarding, guidance and development of competencies of participants in the program.

- ICT, which refers to the promotion and use of digital technologies for learning, interaction and management of information during the development, monitoring and evaluation of mentoring.

- Sustainability, which involves resource and knowledge management, so the program can consolidate and evolve over time.

These factors are articulated with five stages or moments of development:

- Initiation, stage where the components for the creation of a program are still disjointed, with informal mentoring activities that do not yet have institutional visibility.

- Installation, stage where the components are starting to be articulated. Pilot experiences may have been undertaken or initial implementation of a mentoring program in the HEI is expected. 
- Formalization, stage where the articulation of the components is consistent, so it is possible to find reviews of lessons learned, as well as clear relationships with wellbeing or retention processes or programs. Also, guidelines for monitoring, evaluation and ICT use in the development of the program have been established.

- Appropriation, stage that refers to a mentoring program in full operation.

- Consolidation, stage where the program has financial, human, institutional and interinstitutional supports, as well as a system of continuous improvement in operation.

The combination of factors and moments of development produced an analytical tool called DIADEMMA (Diagnosis of Mentoring Moments Development), which helps to assess the status of a mentoring initiative in a HEI, as well as to determine actions needed to move to the next stage, according to its own situation. From a national perspective, this tool allows to compare the situation of different institutions, helping to determine the focus of the technical assistance actions carried out by MoE.

\section{DIADEMMA: Diagnosis of Mentoring Moments Development ${ }^{2}$}

The conceptual elements of DIADEMMA are based on the development model mentioned, while its structure was inspired by the Guide to the implementation of the model of student management and permanence in HE institutions (2015), a tool developed by MoE to assess student retention and graduation in Colombian HEI. In DIADEMMA, each factor groups together key aspects that in turn articulate specific variables, as shown in Table 1.

\footnotetext{
${ }^{2}$ The development of the initial factors of DIADEMMA involved the participation of a team from Cooperative University of Colombia, Medellin headquarters: Reina Cecilia Duque (Head of University Welfare and Alumni), Javier Mauricio Zuluaga (Head of Planning) and Juan David Quiceno.
} 
Table 1. DIADEMMA contents.

\begin{tabular}{lll}
\hline Factor & Key aspects & Variables \\
\hline \multirow{4}{*}{ Positioning } & Articulation with well-being or & Degree of articulation \\
& permanence & Documentation \\
& Responsible authority & Place of coordination \\
& Broadcasting & Consistency and outreach \\
& Diagnosis and characterization & Baseline assessments \\
Tracking & & Mentor profiles \\
& Monitoring & Characterization of students \\
& & Early warnings \\
& Impact evaluation & Analytics and reports \\
& Coordinators & Cost-benefit analysis \\
Training & Guidance to students receiving & Impact analysis \\
& mentoring & Training and guidance \\
& & Training processes \\
& Mentoring & Articulation with other support \\
& Selection & services \\
Management & Pairing & Training and guidance \\
& Incentives & Feedback \\
& Using ICT & Mentor selection process \\
& & Matchmaking criteria \\
ICT & Digital systems for monitoring & Incentive management \\
& & ICT for training \\
& Resource management & ICT for interaction \\
& & Data collection \\
& Knowledge management & Data processing \\
& & Internal resources \\
& & External resources \\
& & Articulation with secondary education \\
& & Interinstitutional work \\
\hline
\end{tabular}

Each variable becomes a question with five possible answers, presented in progressive order. The respondent chooses the one that better describes the program situation at the time assessment is made. Table 2 presents an example referring to the variable "Mentor selection process", articulated to the key aspect "Selection" that is part of the Management factor.

Table 2. DIADEMMA presentation mode.

\begin{tabular}{|c|c|c|c|c|c|}
\hline & Initiation & Installation & Formalization & Appropriation & Consolidation \\
\hline $\begin{array}{l}\text { How are } \\
\text { mentors } \\
\text { chosen? }\end{array}$ & $\begin{array}{l}\text { No } \\
\text { requirements } \\
\text { are } \\
\text { established } \\
\text { for the entry } \\
\text { of mentors. }\end{array}$ & $\begin{array}{l}\text { General } \\
\text { requirements } \\
\text { have been } \\
\text { established } \\
\text { for the entry } \\
\text { of mentors. }\end{array}$ & $\begin{array}{l}\text { Beyond } \\
\text { general } \\
\text { requirements, } \\
\text { the Institution } \\
\text { has established } \\
\text { a formal, } \\
\text { staged process } \\
\text { for mentor } \\
\text { selection. }\end{array}$ & $\begin{array}{l}\text { The mentor } \\
\text { selection } \\
\text { process is } \\
\text { carried out } \\
\text { periodically, } \\
\text { according to } \\
\text { the } \\
\text { requirements of } \\
\text { the mentoring } \\
\text { program. }\end{array}$ & $\begin{array}{l}\text { In addition to } \\
\text { implementing it } \\
\text { periodically, the } \\
\text { mentor selection } \\
\text { process is } \\
\text { evaluated and } \\
\text { adjusted as } \\
\text { neccesary. }\end{array}$ \\
\hline
\end{tabular}


Each response corresponds to development moment, valued from 1 -initiation stage- to 5 consolidation stage-. The average of each factor indicates the stage of that factor; with total average indicating the overall stage of program development, according to the ranges shown in Table 3.

Table 3. DIADEMMA valuation averages.

\begin{tabular}{ccccc}
\hline Initiation & Installation & Formalization & Appropriation & Consolidation \\
\hline 1.0 to 1.8 & 1.9 to 2.6 & 2.7 to 3.4 & 3.5 to 4.2 & 4.3 to 5.0 \\
\hline
\end{tabular}

DIADEMMA was implemented in 41 Colombian HEI in the second half of 2020 and was enriched with further conversations, in order to clarify the conditions and characteristics of existing initiatives and to identify opportunities for improvement. According to the results of these HEI, 16\% have programs in the Initiation stage, 33\% in the Installation stage, $28 \%$ in Formalization -including some in the pilot phase or in the process of reviewing lessons learned and articulating with other institutional areas-, 16\% in the Appropriation stage and $7 \%$ in the Consolidation stage. This shows an interest among participating HEI in such programs, as well as an opportunity to put the experience of the leading institutions at the service of those in earlier stages. As for the factors, the prevalence of development was found in the Positioning factor in contrast to a low level in Sustainability, which indicates the importance of creating networks that can build solutions in this line.

DIADEMMA proposes not only a way to assess the current situation but also actions for the improvement of mentoring programs, given that each possible answer to the questionvariables refers to an action. By identifying which factors and variables require attention, the institution can be guided to take relevant actions to improve its initiative. In this way, each institution can design its own paths of action for the development of its mentoring programs after applying the tool. This takes into account the possibilities of each HEI and a gradual and sustainable process that guarantees the advancement and duration over time of such strategies.

During 2020, the implementation of DIADEMMA was followed by the deployment of support mechanisms between HEI, as well as support in the implementation of programs at the institutional level, all part of the Generation E Mentoring Program. In total, 89 HEI participated, involving more than 2600 volunteer mentors and more than 6500 mentors in the first stage. A new implementation of DIADEMMA is expected at the end of 2021, to account for the development achieved by HEI in their initiatives.

Even though DIADEMMA was developed in the context of Colombina higher education, it could be used by any higher education institution to support the process of assessment and definition of strategies related to institutional-level mentoring initiatives. EAFIT University 
keeps working in the refinement of the tool, as well as fostering exchanges between institutions.

\section{Conclusion}

By facilitating both diagnostic assessment and the identification of development paths, DIADEMMA contributes to the construction of a culture of formative assessment in a higher education institution. In addition, it opens the discussion and planning around the processes of welcoming and supporting students in their integration to higher education. These processes are particularly relevant today, not only because of changes in the skills and needs of new generations -which require improved support mechanisms-, but also because of the circumstances that the COVID-19 pandemic has created in the last year. The massive use of digital technologies to support learning processes brings opportunities as well as challenges for retention with equity.

The development of mentoring initiatives can contribute in the solution of these problems, developing key personal and professional skills and helping in the cohesion of university communities, building bonds and a sense of solidarity. This makes relevant the availability of analytical tools to help HEI to understand their particular situation and development paths. DIADEMMA will have to improve over time, as mentoring programs evolve and the earlier stages become less relevant. At the time, it is a useful tool to foster new discussions and understandings for student retention.

\section{References}

Andrade-Fernandez M., De-Moya L., Encinales S. Moreno J. (2017). Bienestar social en estudiantes beneficiados del programa Ser Pilo Paga: Caso Uninorte I Cohorte 2015. Revista Actualidad Jurídica, No. 9, 10-29. ISSN 2027-8721

Alvarez-Rivadulla M. (2019). ¿"Los becados con los becados y los ricos con los ricos”? Interacciones entre clases sociales distintas en una universidad de elite. Revista Desacatos, No.59, 50-67. Ene-Abr 2019. México. ISSN 1607-050X

Casado-Muñoz R., Lezcano-Barbero F., Colomer-Felui J. (2015). Ten key steps to developing a programme of university mentoring for newly enrolled students. Revista Electrónica Educar, 19(2), 155-180. doi: http://dx.doi.org/10.15359/ree.19-2.10

Chronus. (2017). How to Start a High-Impact Mentoring Program. Retrieved from https://get.chronus.com/rs/910-YDI-216/images/eBook-How-to-Start-MentoringProgram-2017.pdf

Diaz-Velasquez L. (2019). Permanencia de los Estudiantes Ser Pilo Paga en la Universidad Externado de Colombia. (Master's thesis, Universidad Externado de Colombia, Bogotá). Retrieved from https://bdigital.uexternado.edu.co/bitstream/001/2077/1/CBA-spa-2019Permanencia_de_los_estudiantes_Ser_Pilo_Paga_en_la_Universidad_Externado_de_Co lombia 
De Freitas V. (2018). Modelo de madurez en sistema de gestión del conocimiento, desde un enfoque holístico. Revista Cientifica Electrónica de Ciencias Gerenciales, 39(13), 5-31. Retrieved from: http://www.revistanegotium.org/pdf/39/art1.pdf

National Mentoring Partnership. (2005). How to Build A Successful Mentoring Program Using the Elements of Effective Practice. Retrieved from http://www.mentoring.org/downloads/mentoring_418.pdf

Mentors4U. (2021). Mentors4U. Retrieved from https://www.mentors4u.com/

Ministry of National Education of Colombia. (2015). Guía para la implementación del modelo de gestión y permanencia estudiantil en instituciones de educación superior. Retrieved from: https://www.mineducacion.gov.co/1759/w3-article-356272.html

Sapiencia. Medellin Higher Education Agency. (2017). Deserción en la educación superior. Boletín Observatorio de Educación Superior de Medellín ODES, 5, July. Retrieved from:https://www.sapiencia.gov.co/wpcontent/uploads/2017/11/5_JULIO_BOLETIN_ODES_DESERCION_EN_LA_EDUC ACION_SUPERIOR.pdf

Suárez-Castrillón A, Rincón, I, Suárez S. (2020). Impacto del Programa Generación E en la educación superior durante el COVID-19. Revista Espacios, 41(42), 304-314. doi: 10.48082/spaces-a20v41n42p26 